\title{
STRATEGIC MANAGEMENT ANALYSIS IN THE EU COUNTRIES
}

\author{
Antonina Verhun', Mykhaylo Verhun² \\ Kyiv National University of Technologies and Design, Ukraine
}

\begin{abstract}
The concept of national and regional development strategies for small and medium-sized enterprises (SMEs) are studied for a long time, as small and medium businesses are the foundation of the economy and the basis for effective country functioning. The business development program of the European Union countries is particularly interesting because there are several levels that correspond to each other and give full effect on the SMEs development. The EU standards are higher than in non-EU countries; therefore, it is worth considering legislative documents, as well as statistics showing the indicators of openness and access to the development of small and medium-sized enterprises (SMEs). The complexity and comparative novelty of studying such a problem in Ukraine led to the need to explore sources of information in the original language due to the lack of information in Ukrainian or Russian. All these suggest that the problem of creating strategies at the national and regional level is more relevant and important to study in the West that demonstrates the current state. The subject of the study is to analyse the effectiveness of implementing strategies for the development of small and medium-sized enterprises as well as the impact of national and regional policies on their functioning and development in the European Union countries. Methodology. The authors highlighted the peculiarities and main features of the development strategies implementation for small and medium-sized enterprises in the EU countries through a comparative analysis of the legislative framework, statistical and other data that help assess the performance and effectiveness of the implemented strategies. The content analysis helps to identify peculiarities of the implemented strategies in quantitative and qualitative forms. The thorough analysis using the above-mentioned methods allowed doing a qualitative study of national and regional strategies in the context of the development of small and medium-sized businesses in the EU countries. Practical importance is that the results of this study will lead to a wider acquaintance with progressive strategic methods of management of small and medium-sized enterprises. This will enable the plan development of concrete actions to improve the efficiency of enterprise management in less developed countries. In turn, raising awareness on this issue will reduce the number of inefficient and non-innovative enterprises. Scientific novelty of the article is to determine the theoretical basis of the differences that at the current development stage are increasingly manifested as certain contradictions in the compilation and improvement of small and medium-sized enterprises, development of strategies at the national and regional levels. Small and medium-sized enterprises, in their turn, have a wider access to their development. Conclusions. As a result of the main development strategies of small and medium-sized enterprises of the EU countries, there should be identified the differences and common features of different strategies for innovations of small and medium-sized enterprises. The interaction of the national and regional strategy with actual results and existing strategies is explored.
\end{abstract}

Key words: strategic management of enterprises, national and regional strategies, development of small and medium-sized enterprises.

JEL Classification: L100, O018, E610, F200, F430

\section{Introduction}

Consideration of the creation conditions, development and performance of small and mediumsized enterprises in the economies of the European Union countries remain relevant, as enterprises cooperate with each other, regardless of the boundaries and cultural or economic differences. The central place is taken by the state policy that stimulates, supports small businesses with various types of benefits, loans, grants, cooperation encouragement and the experience from other countries. Not only a strategy that is a desirable situation in the future where the enterprise or country should be, but also valid actions that are available for enterprises. A particular attention should

\footnotetext{
Corresponding author:

${ }^{1}$ Department of Finance and Financial and Economic Security Management, Kyiv National University of Technologies and Design.

E-mail: a.vergun@bigmir.net

${ }^{2}$ Department of Accounting and Audit, Kyiv National University of Technologies and Design.

E-mail: vergunm@bigmir.net
} 
be paid to stimulating the development of small and medium-sized enterprises in underdeveloped regions and districts to create new types of businesses, providing technical and financial support. A promising trend is that the emphasis is done on the region strengths, but the weaknesses are taken into account, and there is being developed the strategy of innovation development, which is already a necessity of the modern age. That is, the development of alternative energy sources, the maintenance of a sustainable environment, the natural resources protection are the industries that are receiving the most attention at the moment.

The credit availability, the barrier absence to create bureaucracy and corruption are positive factors for the development of the core of the economy - small and medium-sized businesses.

One of the main categories in business is the longterm planning strategy, indicating the activity goals, the timing of their achievement, tactical plans, and resources that will give a complete picture of how the company or any enterprise sees itself through a certain time interval. A peculiarity is the necessity to adapt the company activities, the production of products or the provision of services for certain regions or countries, for the efficiency and appropriateness of providing their services or goods.

Business strategy is a strategy of business units that determines the direction of action to ensure competitive advantages in a specific area of the organization (Horielov \& Bolshenko, 2010). That is, starting any commercial activity, the entrepreneur should be responsible not only for the beginning of his own enterprise performance but also for further development, the activity direction, that is, the perspective of 3-5 years (sometimes more).

In the literature concerning strategic planning, there are two opposing views on the understanding of the strategy. In the first case, the strategy is a concrete long-term plan to achieve a specific goal, and strategy development is the process of finding a specific goal and drawing up a long-term plan. This approach is based on the fact that all emerging changes are predictable, the processes occurring in the environment are deterministic and fall for complete control and management.

In the second case, the strategy refers to the longterm qualitatively defined direction of the enterprise development concerning the sphere, means and forms of its activities, the system of internal relations, as well as the enterprise position in the environment (Business strategy).

The company strategy is a comprehensive management plan that should strengthen the company position in the market and ensure coordination, attraction, and satisfaction of consumers, successful competition and the achievement of global goals. The strategy development process is based on a thorough study of all possible fields of development and activity, and consists of choosing a common direction, mastering the markets served by needs, competition methods, attracted resources and business models. In other words, the strategy means the company's choice of its path of development, markets, competition methods, and doing business (Examples of business strategies for leading companies in the world).

In other words, the strategy is an integral part of the company's development; it determines the movement direction, taking into account all the information on the advantages and disadvantages. It is important not to forget that the choice of strategy and the possibility of enterprise development are also dependent on state policy and landmarks set by the state itself. That is, the creation of all prerequisites for development is very important for the enterprise performance and their enrichment of the country's economy. This paper concerns SMEs - small and medium-sized enterprises, as they are the basis of any country's economy.

In the developed countries, the share of small and medium-sized enterprises is more than $90 \%$. This is an indicator of the population employment, the population involvement in business processes and the enrichment of their own country's economy. During globalization, we are witnessing the cooperation of SMEs with foreign SMEs and this expands borders, facilitates international trade. However, one should pay attention to the possible barriers that cover international treaties or their absence, taxes and customs duties, which in its turn complicates the trade and does not contribute to the economic development.

It is impossible to predict all possible events that may occur during the strategy implementation. Therefore, it is necessary to use generalized, incomplete and inaccurate information while choosing among various alternatives. In the search process, concrete alternatives are revealed; more information that is accurate appears and can cast doubt on the original choice. The successful strategy implementation is impossible without a constant feedback.

Such concepts as strategies and benchmarks should not be confused. The benchmark is the goal that the company seeks to achieve, and the strategy is a means to achieve the goal. Benchmarks are a higher level of decision-making. A strategy is justified by one set of benchmarks will not be the same if the organization's benchmarks are changed.

After all, the strategy and benchmarks are interchangeable at both individual moments and at different levels of the organization. Some performance parameters (for example, market share) at one point can serve as benchmarks for the firm, and in the other, they will become its strategy. Further, since the benchmarks and strategies are made within the organization, a typical hierarchy arises: the upper levels of control are strategy elements, on the bottom they turn into benchmarks (Sumina, Guseynov, 2016).

Therefore, a regional policy is very important for modern SMEs development. It encourages development, 
innovations, attracts resources and capital, especially for the least developed regions. Therefore, when there is a talk about business development, we should first of all look at the development of regional or national strategies and how they encourage their own SMEs.

When we talk about business activity, the enterprise strategy must start with its origins, namely, the strategy of stimulating entrepreneurial activity at the state level or at the level of the European Union as a whole. This is very important when the state adopts a policy direction that regulates and encourages entrepreneurs to establish enterprises. Nevertheless, the vast majority of the EU countries encourage small and medium-sized businesses, and there are several reasons for this.

The first reason is historical. After World War II, Europe did not immediately recover from those losses and consequences, and in the late 1960s, the European Union had to stimulate small businesses in order to accelerate economic growth. Large companies were subject to severe restrictions on their activities for a number of reasons. In most cases, because they did not want to participate in the development programs of the undeveloped areas, in the process of automation they reduced a large number of workplaces, there was a problem of environmental pollution. In addition, innovation activities also started to decrease.

All of these factors have been combined to stimulate small and medium-sized businesses, which in its turn, for the 21st century, have proven that small and medium-sized businesses account $85 \%$ of the GDP of the European Union (Dryha, 2009).

First, it is worth noting that Small Business Act for Europe is the backbone of the EU policy on SMEs, based on the Think Small First Principle (EUROPE 2020 A strategy for smart, sustainable and inclusive growth, 2010). This principle includes self-advisory and compilation of SMEs opinions, a legislative regulation that refutes business procedures, SBA test that analyses implications of the introduction of some legislative acts for SMEs, and the work of SME messengers promoting SME legal acts and policies.

Among the successful and promising programs for stimulating SMEs development is Horizon 2020, which has been operating since 2014. The main ideas of the program are not only the attraction of a larger number of SBA enterprises but also the innovation stimulations, which has already become an integral part of the development of any enterprise. Consequently, the Horizon 2020 program finances SBA in the amount of 8 billion euros, and advocates joint research and innovation projects (between the EU countries and partners) (SMEs).

That is, such an initiative involves the creation of Innovation Union, which in its turn involves the development of innovations at the local, regional, and national levels. Problems that are central and need to be addressed in the future are energy, transport, climate change, rational use of resources, health, environmental products. In addition, it is planned to expand and improve intellectual property rights (Arabey, 2010).

Moreover, the involvement of educational institutions and a creative approach to learning and the use of skills acquired during the training period is also a priority for the EU countries. The strategy encourages young graduates to innovate through scholarships and financial assistance, as well as ongoing consultations and trainings.

All these and much more are aimed at implementing the following principles by 2020 :

- smart economy's development based on knowledge and innovations;

- sustainable growth - encouraging productive use of resources, "green" and more competitive economies; - inclusive growth - promoting economies with high levels of employment that coordinate economic, social, and territorial growth (The Small Business Act for Europe).

Another initiative of COSME (the Competitiveness of Enterprises and Small and Medium-sized Enterprises) will provide financial assistance and guarantees for small and medium-sized businesses at all stages of the enterprise establishment. This program also helps entrepreneurs with training, education and advice to support their activities. You can also add that the program is aimed at creating the right environment for creating and running a business (annual report on European SMEs 2015/2016, 2016).

Looking at the growth of SMEs in 2013-2015, it can be seen the following: from $-1 \%$ in 2013 to $1.1 \%$ in 2014 and $1.5 \%$ in 2015 . For comparison, one can draw attention to the level of large enterprises growth: from $0.3 \%$ to $1 \%$ in 2014 and $1.3 \%$ in 2015 . That is, SMEs have started to develop more dynamically (EU Status Report 2016: Strengthening European Investment for Jobs and Growth, 2016).

It is possible to trace the employment growth and the level of the added value in the EU countries. The employment grew from -1\% (2013) to $1.5 \%$ (2015), and the added value increased from $1.45 \%$ (2013) to $5.7 \%(2015)$. That is, we see a clear growth and progress made by the EU countries after the adoption of SMEs stimulus programs.

It is also worth noting the new EU strategy, which covers the regulation of foreign investment by 2030 . It provides advice on the creation of a new European External Investment Plan, in order to maintain employment levels in Europe, as well as throughout the world. According to this plan, the European Strategic Investment Fund is expected to attract 116 billion euro in 26 member countries for more than 200000 small and medium-sized enterprises (Arutyunova, 2010).

That is why we see that the framework for legislative regulation and stimulation of SMEs has had the result, so for the full analysis and comparison of the strategies 
of the EU countries, it is necessary to consider the enterprises of some countries and to analyse the state strategies of business stimulation.

At present, the general attention of the business towards the strategy is rapidly increasing. The methods of network strategic planning are being developed and implemented when the strategy is formed simultaneously and agreed on several technologically or functionally related enterprises. There are whole "clumps" of territorially close or functionally related enterprises operating on the basis of an agreed strategic perspective (such groups of companies have been called "business systems"). At the same time, the strategies are rarely complex in nature, which significantly reduces their reality, effectiveness and efficiency.

That is, the company strategy is the central part of the entire enterprise, sets the main directions, goals and a general sense of the business existence. It is important to choose the right strategy, which can provide new competitive advantages, development in the modern period, and plays the main role of any enterprise - to make a profit.

The conclusion can be implied that the enterprise strategy and the potential for enterprise development depend on a properly chosen national strategy, so one should look more closely at the examples of the European Union and other foreign countries to understand, which strategies are promising and which directions are important for the successful development.

\section{Strategic development analysis of SMEs in Poland}

National strategies for encouraging SMEs are a very important issue for the EU that seeks to develop basic things to achieve enormous success at the highest level.

Polish experience shows that in 2014 the growth of the added value was at the level of $4.6 \%$, and by $20156.9 \%$. The workplace creation in $2008-2014$ was $4,6 \%$, and in $2015-1.6 \%$. The forecasts for the same indicators for $2016-2017$ are $0.2 \%$ the added value and $4.8 \%$ for workplace creation. As a whole, in 2015 for 100 inhabitants, there are $4.1 \%$ of companies (Small and medium enterprises in Poland - obstacles and development).

The main trends in the enterprises' development in Poland are:

- the sector in Poland is smaller than in the other EU countries and the number of enterprises is the smallest among the other EU countries. The profit is $36 \%$, which is one third less than the big companies receive;

- the most widespread are companies engaged in industry and trade;

- small and medium-sized enterprises take three times more loans from banks, which in turn leads to the fact that among the debtors, there are more SMEs than large companies;
- SMEs have the same average growth rate as big businesses, but they are more dependent on market fluctuations, so the added value has not returned to the level of 2014;

- SMEs development is focused on improving productivity because they make better use of resources and workforce. This leads to the conclusion that the contribution of Polish SMEs to innovative development is greater than in the added value;

SMEs invest more in people than in equipment. SMEs allocate one-third of their profits to people, so the number of the involved in SMEs is constantly increasing;

- the biggest barrier to growth is large taxes and bureaucracy;

- the access to bank loans is much easier than in the other EU countries. As a result, the enterprises that receive loans are twice as likely to spend on innovation; - SMEs have a problem in finding qualified staff that has the necessary knowledge and skills in managing SMEs. But despite this, Polish companies rarely encourage their employees to acquire additional skills; - small businesses are slowly developing.

It should be noted that there is no state regulation of SMEs in Poland. The valid documents fall within the jurisdiction of the entire EU. The promotion of SMEs development is provided by the EU funds. At the state level, there are government agencies and ministries that have financial assistance programs primarily for innovation and human capital, as well as counselling, training, and development.

There are also regional programs, but among them are priority projects of an innovative nature. Polish Business Development Agency (PBDA) operates in Poland, which manages budget funds and funds allocated by the EU to implement programs. It also provides counselling, information, training, and financial services.

The state strategy focuses on such priority tasks as increasing innovation, developing small businesses in the eastern regions of the country, improving the workers' skills, reducing bureaucratic procedures, and opening a wider access to business development.

The negative phenomena of SMEs development are (as a percentage):

- taxes size (20\%);

- tax collection system ( $8 \%)$;

- labour legislation (9\%);

political instability (9\%);

- access to finance (13\%);

- workforce insufficient qualification (3\%);

- business licensing and permissions (3\%);

- corruption (3\%) (21).

On the example of Warmian-Masurian Province, the strategy of small business development until 2025 was developed. This region is industrial only for 33\%, which is below the average in Poland - 33.5\% (annual report on European SMEs 2015/2016, 2016). It has 
the highest unemployment rate and the lowest GDP. It is assumed that the GDP of this province will grow from $0.06 \%$ (2010) to $0.7 \%$ by the end of 2020 . And the number of innovative enterprises will increase from $12.4 \%$ (2011) to 22\% (2020) (Bei, Tomson, 2013).

In order to develop a strategy, there were conducted analyses of the positive aspects of this region and its benefits. It is a clean environment, therefore, the potential for the development of tourism and light industry (food, forestry) is most likely. In addition, there is potential for the renewable energy development sources. In the region, the presence of foreign investors is small.

Onthisbasis,someprioritygoalsare developed. Thefirst goal is an effective SMEs support policy that is benefits, financial support, and easier access to information and technological innovations. The second one is the involvement of a large number of domestic and foreign investors - programs for attracting investment, creating economic zones. The third goal is the involvement of public organizations of entrepreneurship - promoting entrepreneurship at the school level, educational programs and activities of organizations. The fourth one is increasing the economic potential of small enterprises competitiveness - the creation of innovation centres, research centres, technology parks, and support for innovation initiatives. The fifth goal is the development of the information society - the computerization and increase of the Internet access (Measures to stimulate business and employment in VSEs and SMEs, 2015).

Therefore, a detailed analysis, identifying strengths and weaknesses, as well as thinking for the future, helps to find ways to create a strategy, identify the priority goals and objectives, without which this strategy will not work. It is very important to set real goals and allocate enough time for their implementation.

\section{Development analysis of small and medium-sized business in France}

Another country, which strategy will be considered, is France. During 2014, the added value of SMEs was $0.3 \%$, and in 2015 it was $2.6 \%$, the number of enterprises per 100 inhabitants was at the level of 4.5. If to consider the workplace creation, then it can be seen that for the period of 2008-2014, 17.9\% of workplaces were created, but 2015 represents only $0.1 \%$.

Taking into account the common features, it should be noted that less than $50 \%$ of the population is involved in SMEs. Small and medium-sized enterprises represent 99.8\% of French business (SME Investment and Innovation France, Germany, Italy and Spain, 2015). When it comes to investment and innovation, one can note the following:

- weak economy of recent years has led to a reduction in the allocation of funds for innovation due to fears of uncertain economic conditions; another problem is reducing the demand for SMEs and small profits;

- for a long time investments were high, but they went to construction, so we can talk about a decline in SMEs investment;

- French innovators show good results but still remain below the EU average (SME Performance Review, 2016).

Speaking about state regulation, it should be noted that SMEs are involved in the Ministry of small and medium-sized business, trade and crafts, and regional offices. France is actively implementing the principles of Small Business Act for Europe. In 2015 and the first half of 2016, 3 out of 10 principles were implemented (Measures to stimulate business and employment in VSEs and SMEs, 2016).

In the summer of 2016, the prime minister of France said that starting from 2017 the tax rate would decrease from $33 \%$ to $28 \%$. However, he did not mention whoever this reduction will be applied, it is only a part of those whose income does not exceed a little more than 38 thousand euros. Moreover, the tax on credit will increase from $6 \%$ to $7 \%$ (Summary of french regions' regional innovation strategies, 2012). Nevertheless, despite this, it is argued that the "SMEs test" is not yet sufficiently developed, which determines the impact of the adopted laws on the actual state of affairs.

To review the strategy for the poorly developed region, the authors chose the province of Auvergne, which is on the level 20 according to the French economy with the lowest GDP and employment rates (Auvergne Smart Specialisation Strategy, 2014). The location without access to the sea, inside the country, is not very favourable. However, it is necessary to dismantle the weaknesses and strengths.

Weaknesses can be determined such factors as the outflow of the able-bodied population, a large number of microenterprises that do not have a certain structure, are family businesses and are not engaged in innovation, insufficient research into innovations in industries that are dominant in the region - chemical, machine building, metallurgy, not effective regional policy that does not contribute to business development.

Strengths are the presence of private research companies, good results in implementing the allocation of funds from the funds for SMEs development, the basis for conducting research.

Therefore, with the help of Structural Funds and the Cohesion Fund (2014-2020), a Smart Specialization program was selected. The province Auvergne has developed five priority goals:

The first goal is to produce and supply the market with more health and well-being products. The second goal is to develop new products and services for sustainable agricultural production. The third goal is to improve the attractiveness of the area by establishing sustainable living spaces. The fourth goal is to ensure physical and 
digital tracking of events. The fifth goal is to strengthen the information gathering and analysis system and the enforcement system (Regional Council of Auvergne).

For this in 2014, 10\% of the budget funds went to the development of regional programs. Since that year, a program called "Digital Auvergne" has been launched, which is developing high-speed networks throughout the region. All priority development directions are initiated by the executive service of Regional Council (Profile the SME sector in Germany, 2015).

That, France is trying to lower taxes and encourage the opening of new SMEs to launch the economy and its growth after an all-embracing crisis throughout the European Union. A detailed program for the development of economically backward regions and close monitoring of its implementation by the EU government structures will help to see the outcome of reforms in the near future.

\section{Germany's experience in implementing SMEs reforms}

In Germany, SMEs account for $99.7 \%$ of all commercial enterprises, with 2.7 enterprises per 100 inhabitants. In 2014, GDP growth was $3.8 \%$, and in 2015 it was $4.2 \%$. Regarding employment, in the period from 2008 to 2014 , it was $20.2 \%$, and in 2015 it was $1 \%$, but the total number of working people at SMEs was $68 \%$ of the total able-bodied population (The German Mittelstand - an Overview, 2012).

The most important thing to note when it comes to the development of SMEs in Germany is the so-called Mittelstände, which are the backbone of the German economy because they are family businesses. They are characterized by a high degree of managerial interest as a result, a high degree of specialization, flexible decisionmaking, long-term focus on responsible organizational culture, long-term training and additional education, decentralized presence (The Central Innovation Programmers for SMEs, 2017).

In addition to public policy and the EU policies, such a program of encouragement is the Central Innovation Program of SMEs for those enterprises wishing to develop new or thoroughly improve the existing products, processes or technical services. The program was presented in 2008, with a rethinking of the principles in 2015 and will be in place by the end of 2019. All SMEs with a number of workforce up to 499 can apply for individual assistance or in co-operation with other enterprises.

There is also a special regulation for transnational projects, which includes the IraSME Network, a network ofministries and sponsoring agencies that are coordinators or holders of national or regional collaborative research programs between SMEs. The research and technology companies are also invited to participate. There are also international cooperation agreements with foreign partners, but only German companies can receive funding (Regional Innovation Strategy 2020 for MecklenburgWestern Pomerania, 2014).

Looking at regional development strategies, it is possible to have a look at Mecklenburg-Vorpommern, which in 2013 contributed $1.83 \%$ to the national GDP and $11.2 \%$ of unemployment, which took the 2 nd place in the number of the unemployed after Berlin (Auvergne Smart Specialisation Strategy, 2014). The regional development program for 2014-2015 was presented in 2013. The SWOT analysis identified the following priority areas:

- energy and climate;

- sustainable development and new materials;

- health and biomedical sciences;

- food industry;

- mobility;

- information and communication technologies.

The main activities were also highlighted, among them the strengthening of state support towards SMEs, the provision of venture capital for $R \& D$, the maintenance of the establishment of industrial parks, and platforms for discussing further initiatives (OP MecklenburgVorpommern ERDF 2014-2020, 2014).

There were also indicated expected results:

- at least 150 projects at enterprises collaborating with research centres;

- more than 5,500 workplaces;

- investments support in 380 SMEs in the amount of more than 600 million euros;

- reduction of carbon dioxide emissions by the equivalent of more than 20 thousand tons of $\mathrm{CO}_{2}$;

$250 \mathrm{~km}$ of new or expanded cycling lanes (along with municipal roads) and $200 \mathrm{~km}$ of new or expanded leisure cycling lanes;

- 80 thousand sq. $m$ of created or restored open space; - 200 new or upgraded public and educational infrastructure in 230 thousand square meters (Unemployment rates, seasonally adjusted).

That is, the German economy has its own "trump cards" to increase and sustain the productivity of SMEs or to encourage their performance. The state of the economy, from which the regional development programs began to operate, was one of the best in the whole EU, so the results for 2020 should be very positive.

\section{Greece's regional strategies for SMEs support}

It would be interesting to consider the regional strategies of countries, which are in debt crisis. Let us consider the example of Greece, which has been in a state of crisis for a long time and is now faced with difficult times of debt obligations and negotiations with creditors.

For the period of 2008-2014, the level of employment reached $24.3 \%$. Now the indicator has not changed 
significantly 23.5\% (The Central Innovation Programme for SMEs, 2017). The added value for SMEs for the period $2008-2014$ is $-0.7 \%$. According to 2015 , it is $-1 \%$. However, for 100 inhabitants there are 6.5 SMEs.

It should be noted that microenterprises are the basis of the Greek economy (2016 SBA Fact Sheet Greece, 2016). In general, SMEs are $3 / 4$ of the added value and $90 \%$ of employment in the country (The Small Business Act for Europe). Nevertheless, SMEs have not been able to reach the level of large firms, which saw an increase of $19 \%$ from 2008 to 2015.

Such an indicator as access to financial resources is the lowest in Greece in the EU countries. Moreover, this means that credit financing is not sufficient for the development of SMEs in the country, including venture capital. In addition, their debt is gradually increasing.

The initiatives launched by Greece at the state level try to remedy the situation and improve the state of the economy. The EU programs and commitments to lenders are aimed at the overall development of the economy and the focus on innovations. One of these is Research and Innovation Strategies for Smart Specialization (RIS3), implemented by 1 national and 13 regional strategies, focusing on the following areas:

- agri-food;

- health and medicine;

- information and communication technologies;

- power engineering;

- environment and sustainable development;

- transport;

- materials and construction;

- tourism, culture, creative industries.

The strategy for the introduction of these strategies has created a specialty strategy council of smart specialization, consisting of representatives of ministries and regional bodies, as well as regional councils in 13 regions of Greece (OP Competitiveness, Entrepreneurship and Innovation, 2017).

The program of Competitiveness, Entrepreneurship and Innovation is very interesting and it is a detailed plan and continuation of the program mentioned above. The priorities are:

- entrepreneurship development support with sectorial priorities;

- adaptation of workers, enterprises and business environment to new development requirements;

- mechanism development for supporting entrepreneurship;

- technical support.

Among the expected results:

- increased R\&D and innovation costs from $0.34 \%$ to

$0.51 \%$ of GDP in all regions;

- introduction facilitating of information and communication technologies for SMEs;

- the Internet speed increase;

- help more than 1000 companies to develop new products; help at least 22.5 thousand enterprises and create more than 8 thousand workplaces;

- increase the use of alternative energy sources, improve energy efficiency, etc. (Local Analysis North Aegean Greece, 2017).

It is interesting to consider an operational program aimed at developing the region that brings the country's lowest GDP profits - the North Aegean islands. The SWOT method has identified strengths and weaknesses. Among the strengths, there are natural and cultural resources, the availability of powerful educational resources and the research base, the presence of Greek banks. But each of these strengths has a negative side, for example, insufficient investment in natural resources to save them, insufficient investment in education and research, and limited cooperation between educational institutions and enterprises (North Aegean OP, 2014).

Basing on these data, a strategy for 2014-2020 was developed, aimed at:

- entrepreneurship support and stimulation, especially SMEs;

- entrepreneurship and investment involvement in research and development;

- strengthening the role of information and communication technologies;

- employment increase and more people attraction;

- health and social security improvement;

- environmental protection and sustainable development.

The expected results:

- support for 35 new SMEs and encouraging cooperation of 15 enterprises with educational institutions;

- creation of 140 workplaces, etc. (Small and medium enterprises in Poland - obstacles and development).

That is, Greek strategies, as well as the EU-wide regional development strategies, are also detailed and look very successful, but only actual results will show the effectiveness of the chosen and implemented strategies, taking into account the deep economic crisis in Greece, which is one of the most serious.

Considering the EU strategies, we see the hierarchy of decision-making - the overall strategy of the European Union goes to others, "lower" levels - national, and those are divided into regional ones. Each level has its own control and enforcement authorities, so it is easy to follow responsibility, and who is responsible for it.

It can be concluded that SMEs support and development strategies are present at different levels in the EU countries. There is a level of the Union and there is a national level. The strategies are detailed, very clearly developed, which must make their result in their implementation. However, according to already existing results, we can say that the success of such changes and the implementation of strategies depending on the general situation in the country that the above examples have demonstrated. 


\section{Conclusions}

The key principles for developing a strategy for small and medium-sized enterprises is a documentary level in the form of laws both national and regional strategies, financing business incubators and encouraging the opening of innovative enterprises for those regions in need. It also includes attraction of foreign capital and stimulation of cooperation within the EU and with the countries-EU partners are a powerful policy for SMEs development and innovation, which is a priority in the modern era.

Having analysed the existing strategies and the results, it can be said that these results reflect the general tendency of the enterprise development. For example, in Germany, small family businesses formed the basis for the development and growth of the economy after World War II. The protracted crisis in Greece, which has led to an unsatisfactory state and still requires radical actions, gives such a reality where the promotion of small and medium-sized businesses is not very effective since the population is in poor financial position and lending is not sufficiently developed to provide the opportunity to finance entrepreneurs. The same approach can be applied to Poland, where small and medium-sized businesses are developed, but there are still obstacles that prevent more people from engaging.

The conclusion can be drawn that the presence of SMEs, the level of their development is an indicator of the development of the whole country and the economy as a whole. The mechanism of stimulation, promotion of small and medium-sized businesses reflects the general tendencies towards the awareness of the need for SMEs development and the cultivation of a distinctive business culture, which is the basis for the innovative and progressive development of the country's economy.

\section{References:}

2016 SBA Fact Sheet Greece (2016). Retrieved from: http://www.ggb.gr/sites/default/files/basic-page-files/ Greece\%202016\%20SBA\%20Fact\%20Sheet.pdf. (accessed January 2018)

ANNUAL REPORT ON EUROPEAN SMEs 2015/2016 (2016). Available at: http://ec.europa.eu/growth/ smes/cosme/ (accessed June 2017)

Arabey E. (2010). Novaya evropeyskaya strategiya "Evropa 2020". [The new Europe 2020 strategy] Retrieved from: http://eulaw.ru/content/307. (accessed June 2017)

Arutyunova D. V. (2010). Strategicheskiy menedzhment: ucheb. posobie [Strategic management] Taganrog: Izd-vo TTI YuFU. $122 \mathrm{p}$.

Auvergne Smart Specialisation Strategy (2014). Retrieved from: https://ec.europa.eu/growth/tools-databases/ regional-innovation-monitor/policy-document/auvergne-smart-specialisation-strategy (accessed June 2017)

Bei O., Tomson H. (2013). Zarubizhni praktyky rozrobky stratehii rozvytku maloho pidpryiemnytstva na rehionalnomu rivni. K.: K.I.S. 48 p.

Business strategy. Retrieved from: http://businesscasestudies.co.uk/business-theory/strategy/business-strategy. html\#axzz4Rx8ZuC6P. (accessed June 2017)

D.O. Horielov \& S.F. Bolshenko (2010). Stratehiia pidpryiemstva [Enterprise strategy]. Kharkiv, KhNADU, 133 p. Doklad o polozhenii del v ES 2016: Ukreplenie evropeyskikh investitsiy v tselyakh sozdaniya rabochikh mest i sodeystviya rostu [EU Status Report 2016: Strengthening European Investment for Jobs and Growth] (2016). Retrieved from: https://eeas.europa.eu/delegations/russia/14528/doklad-o-polozhenii-del-v-es-2016ukreplenie-evropeyskih-investiciy-v-celyah-sozdaniya_ru. (accessed June 2017)

Dryha S. H. (2009). Suchasni tendentsii rozvytku rozvytku maloho biznesu v krainakh Yevropeiskoho soiuzu [Modern trends in the development of small business in the countries of the European Union]. Retrieved from: http://www.stplan.ru/articles/theory/bizstrat.htm. (accessed January 2018)

EUROPE 2020 (2010). A strategy for smart, sustainable and inclusive growth Retrieved from: http://ec.europa.eu/eu2020/pdf/COMPLET\%20EN\%20BARROSO\%20\%20\%20007\%20-\%20Europe\%20 2020\%20-\%20EN\%20version.pdf. (accessed May 2017).

LocalAnalysisNorthAegean Greece(2017). Retrievedfrom:http://www.ptaba.gr/dyn/banner/061215142847_b. pdf. (accessed January 2018)

MeasurestostimulatebusinessandemploymentinVSEsandSMEs(2016)Retrievedfrom:https://home.kpmg.com/ $\mathrm{xx} / \mathrm{en} /$ home/insights/2016/08/tnf-france-reduced-corporate-tax-rate-increased-tax-credit-for-sme.html/ (accessed June 2017)

Measures to stimulate business and employment in VSEs and SMEs. (2015). Retrieved from: http://www.gouvernement.fr/en/measures-to-stimulate-business-and-employment-in-vses-and-smes. (accessed June 2017)

North Aegean OP (2014). Retrieved from: http://ec.europa.eu/regional_policy/EN/atlas/programmes/20142020/\%5Eportugal/2014gr16m2op010. (accessed January 2018)

OP Competitiveness, Entrepreneurship and Innovation (2017). Retrieved from: https://www.espa.gr/en/pages/ staticOPCompetEntrepInnov.aspx.

OP Mecklenburg-Vorpommern ERDF 2014-2020 (2014). Retrieved from: http://ec.europa.eu/regional_policy/ EN/atlas/programmes/2014-2020/ital/2014de16rfop008. (accessed January 2018) 
Primery biznes-strategiy vedushchikh kompaniy mira. [Examples of business strategies for leading companies in the world] Retrieved from: http://www.stplan.ru/articles/theory/bizstrat.htm. (accessed May 2017)

PROFILE THE SME SECTOR IN GERMANY (2015). Retrieved from: https://www.kfw.de/migration/ Weiterleitung-zur-Startseite/Homepage/KfW-Group/ Research/PDF-Files/The-SME-sector-in-Germany.pdf. (accessed January 2018)

Regional Council of Auvergne. Retrieved from: https://ec.europa.eu/growth/tools-databases/regionalinnovation-monitor/organisation/regional-council-auvergne. (accessed January 2018)

Regional Development Strategy of the Voivodeship of Warmia and Mazury until 2025. Retrieved from: https:// ec.europa.eu/growth/tools-databases/regional-innovation-monitor/policy-document/regional-developmentstrategy-voivodeship-warmia-and-mazury-until-2025. (accessed June 2017)

Regional Innovation Strategy 2020 for Mecklenburg-Western Pomerania (2014) Retrieved from: https://ec.europa.eu/growth/tools-databases/regional-innovation-monitor/policy-document/regionalinnovation-strategy-2020-mecklenburg-western-pomerania. (accessed January 2018)

Research and Innovation Strategies for Smart Specialisation (RIS3) (2017). Retrieved from: https://www.espa.gr/ en/pages/staticRIS3.aspx. (accessed January 2018)

Small and medium enterprises in Poland - obstacles and development. Retrieved from: https://www.politykainsight.pl/multimedia/_resource/res/20105186. (accessed June 2017)

Small and Medium-sized Enterprise Basic Act (2002). Retrieved from: http://www.chusho.meti.go.jp/sme_ english/outline/08/01_02.html\#01. (accessed January 2018)

SME Investment and Innovation France, Germany, Italy and Spain (2015). Retrieved from: https://www.kfw.de/ $\mathrm{PDF} /$ Download-Center/Konzernthemen/Research/PDF-Dokumente-Studien-und-Materialien/SMEInvestment-and-Innovation-October-2015.pdf (accessed June 2017)

SME Performance Review (2016). Retrieved from: http://ec.europa.eu/growth/smes/business-friendlyenvironment/performance-review-2016_en.

SMEs. Retrieved from: https://ec.europa.eu/programmes/horizon2020 /en/area/smes. (accessed January 2018) Sumina E.V., Guseynov A.I. (2016). Kontseptsiya klyuchevykh kompetentsiy kak osnova upravleniya konkurentnosposobnostyu sotsialno-ekonomicheskikh sistem [The concept of key competences as a basis for managing the competitiveness of social and economic systems] Ekonomicheskie nauki, p. 52-54.

Summary of french regions' regional innovation strategies (2012). Retrieved from: http://s3platform.jrc.ec.europa.eu/ documents/20182/141136/Summary_FR_Regions.pdf (accessed May 2017)

The Central Innovation Programme for SMEs (2017). Retrieved from: http://www.zim-bmwi.de/zim-overview. (accessed January 2018)

The development of SMEs in Greece (2014). Retrieved from: http://www.gsevee.gr/press/mme_eng.pdf. (accessed January 2018)

The German Mittelstand - an Overview (2012). Retrieved from: http://www.dcmsme.gov.in/Policies/ International\%20Policies/The\%20German\%20Mittelstand_An\%20Overview.pdf. (accessed January 2018)

The Small Business Act for Europe. Retrieved from: https://ec.europa.eu/growth/smes/business-friendlyenvironment/small-business-act_en. (accessed January 2018)

Unemployment rates, seasonally adjusted. (March 2017). Retrieved from: http://ec.europa.eu/eurostat/statisticsexplained/index.php/File:Unemployment_rates,_seasonally_adjusted,_March_2017_(\%25)_F2.png (accessed January 2018) 